\title{
THE ROLE OF THE LEADER IN THE SUCCESS OF THE CHANGES IN AN ORGANIZATION
}

\author{
Jeton Zuka \\ Faculty of Economics - Prilep, Macedonia
}

CMESTE

JEL Category: D23, J53

\begin{abstract}
Today, in the age of globalization, every organization strives to achieve given objectives in the most efficient and effective way. The rapid pace of change in the business environment, identification of new opportunities and taking quick action is a real challenge for any leader, as a matter of fact, it is a question of the survival of the organization itself. The organizations today are faced with many problems, and one of them is the lack of vision and lack of professionalism in the working. The purpose of this paper is to point out and establish the relationship between the role of the successful leader, his values and how he uses these values in the process of introduction of successful change in the organization. In difficult and decisive moments for an organization, in terms of rapid and unpredictable changes in the organization, there is a need for a leader, a man who can introduce changes in the organization, to organize and manage the transformation of the organization, which will lead to more efficient and effective operations thereof. The efficiency and the performance of the leader represents one of the most important elements in the change process in the organization. The success of the organizational changes depends on the ability of the leader to guide the others in the process of changes, to know how to motivate and timely remove obstacles in the process of changes in the organization. Any mistake in any phase of the process of change is catastrophic, that is why the leaders should be well informed and prepared for what will follow.
\end{abstract}

Keywords: leadership, managers, change, organization, efficiency

\section{INTRODUCTION}

Today, the changes are inevitable, rapid and unpredictable, and the leaders are forced to introduce the change and to adapt the organization according to the new trends and developments in the environment.

The address of the author: Jeton Zuka

䒠=” jetonzuka@live.com
Organizations continuously are facing the changes, which as a difference in their state of play between two points in time, starting and ending position, require changing of the old norms and values with new ones. By applying the changes, the organization strives to improve its efficiency, its performance and the way individuals and groups work. Effective managers - leaders should recognize the need for changes, expect constant changes and consider such changes as necessary and useful for the organization. 
Today, we see a number of reasons that determine the occurrence of the organizational changes, such as, the external environment manifested by the globalization, changing the role of the market, demographic changes, shifting of the factors and parameters of the organizational structure and others.

In difficult and decisive moments for an organization in terms of rapid and unpredictable changes in the same, there is a need for a leader, a man who can introduce the changes in the organization, to organize and manage the transformation of the organization, which will lead to more efficient and effective operations thereof. Thanks to its features that distinguish him, such as honesty, trust, respect for others and the organization, intelligence, knowledge, experience, etc., the leader can provide a smooth transition from the current state of play of the organization to the desired state of the same. He has the power to influence employees and create trust, respect and confidence and achieve the goals of the organization and applies changes, and therefore build one successful organization. To achieve this, it is necessary for the leader to be familiar with the environment of the organization, especially employees, to know how to communicate, motivate, and above all to know how to behave in certain situations.

The efficiency of the performance of the leader represents one of the most important elements in the process of change in the organization. $\mathrm{He}$ is the first person in the organization (leader), as an example for the rest, which helps guide the organization towards the realization of the set goals, and a creator of the relationships in the organization. The success of the organizational changes depends on the ability of the leader to guide the others in the process of changes, and to know how to motivate and timely remove obstacles in the same. Any mistake in any phase of the changes is catastrophic, and that is why the leaders should be well informed and prepared for what will follow.

Leadership is the influence towards the people by setting goals, guidance, motivation and management while working, in order to accomplish the given tasks and goals. A leader knows how to motivate, organize and manage a group of people and lead them towards working that will have the only purpose of achieving the determined objectives, but he also knows to be responsible and liable for the entire group. Leadership is a cooperative effort fostered by listening, gathering a variety of opinions, considering effective strategies and effectively generating a clear vision.

Leaders are focused on one of the main resources in any organization, the staff. The leaders communicate the vision for change or the vision for the future, motivate people, remove the obstacles in the processes of changes and the process of the operations in the organization, and encourage the involvement of individuals or groups in the processes of changes and achieving the set goals.

There is one wrong theory that leaders are born, not created. But, according to Peter Drucker (Hausladen, 2008): "Leaders are not born; they are grown". It is normal that there are people who are naturally charismatic, visionary and have the ability to impose their personality on others, induce others to follow, but the conclusion that a leader cannot be created is a wrong conclusion. Leadership can be learned and anyone can be a leader. Every organization needs a leader, especially in the process of organizational changes, when the need for a leader is even bigger. Leadership is further challenged by the ability to motivate others, often over a long period of time, and guide others effectively. Peter Drucker (1999) stated, "Management is doing things right; leadership is doing the right things."

Possession of quality characteristics of the leader gives him the power to influence to the attracting of the attention of the group, individuals, organization and beyond, to attract followers, to motivate and mobilize followers towards achieving the vision of the company and implementation of the organizational changes. This characteristic is not just a natural gift; it is a characteristic that can be learned over time. The leader should have a value system built on permanent values, in fact, precisely that build system of permanent values separates the leader from the other people in the organization and allows him to rise above the rest, to lead and to make a positive impact on the others in the process of achieving goals in the organization. The literal definition of leadership is "the behavior of an individual when he is directing 
the activities of a group with a focus on a shared goal." Although there are thousands of documented definitions of what leadership is, essentially it always incorporates the ability to influence individuals with the objective of achieving an intended goal. Leadership depends on minimizing the risk to ensure that the trust factor is solid. As a leader, the ability to maintain high levels of trust comes through consistent actions, honesty, expertise, confidence, and clarity.

What is it that sets the leader apart from the other people in the organization? A successful leader has many positive features. Successful leaders are intelligent enough to understand the needs of others, know the necessity of commitment, be energetic, possess the courage of persuasion, and have an innate integrity.

The employees have great respect for the leader, because of the characteristics that he possesses, such as:

- visionary,

- honesty,

- inspiring,

- effective,

- fair,

- communicative,

- courage etc.

The given features guarantee that a leader will be successful if he possesses them more or less, but the success of a leader depends on the situation in which he acts. The success in the implementation of the organizational changes, interpersonal skills, the personal capacity and focusing on the results which are the basis for the realization of the objectives of the organization and implementation of the vision, are personal characteristics of a successful leader.

\section{PERSONAL CHARACTERISTICS OF THE LEADER}

Possession of quality characteristics gives the leader the power to influence to the attracting of the attention of the group, individuals, organization and beyond, to attract followers, to motivate and mobilize them toward achieving the vision and implementation of organizational changes. It is not just a natural gift, and it can be learned over time, as it was explained in (Ristic \& Cekerevac, 2012). Every leader should have built-in value system with lasting values, in fact, precisely, this system of permanent values separates the leader from the other people in the organization and enables him to rise above the rest, to lead and to make a positive impact on others in achieving the goals set. The true task of leadership involves the ability to make all changes happen. About young professionals' leadership skills, it is discussed in (Kiteva Rogleva, Gegovska-Zajkova, \& Fustik, 2014).

Numerous studies show that some features of leadership, more or less, are repeated and these characteristics represent the features of a successful leader. These common characteristics include intelligence, initiative, and persistence in problem solving, motivating others, need for highlighting, accepting responsibility etc. Exactly these features enable the leader to introduce successful changes in the organization. Although many studies have been done on what makes a leader successful and effective, there appears to be no guaranteed consensus. During the time, outstanding leaders become a fine balance between traits, abilities, behaviors, sources of power, and aspects of the situation. Leaders become the determining factors of the ability to influence followers and accomplish group objectives. Leaders also need the confidence to build self-esteem in others and still maintain a strong degree of integrity in themselves. One leader must be able to gain the approval of everyone involved in order to make an idea reality. The ability to develop cooperative relations, to be a team player and to create an atmosphere that supports a high degree of collegiality, marks the true leader.

The most effective measure of a leader and his/her competency is the extent to which the group attains its goals. It is easy to see why Stephan Covey, author of The 7 Habits of Highly Effective People, said: "Begin with the end in mind." Formulate an idea and then work through the details to commit every thought, feeling, and emotion knowing that you can portray it with confidence and honesty. It incorporates attitudes, values and a mindset that can facilitate commitment and transformation. Leadership begins by developing a vision, a desire or picture of how an organization will look in the future. Often it represents an idea or dream of what might be or could be. It's the classic "If only..." statement. A 
leader is capable of taking this "if only..." and bringing it to life. In reality, a vision denotes the "what" and the leader represents the "how" or the elements of what needs to be done to achieve the vision.

Effective leadership begins with the fundamental ability to believe in yourself. The leaders believe in people, are sensitive to other's needs and appreciate a person's core values. The leader will actively remake a challenge to yield productive outcomes by creating an organization that develops and fosters success. Although often debated, leadership characteristics can be learned skills that with encouragement and reinforcement can produce outstanding individuals. The leaders are disciplined thinkers and confidently trust their intuition, they have a vision, confidence to adopt the role of instilling motivation, self-esteem, and teamwork. Leaders understand fully their environment and can transform situations to attain an established vision. People expect leaders to speak out on matters of values and conscience. But to speak out, you have to know what to speak about. First, find your voice. Second, affirm shared values (Kouzes \& Posner, 2012).

Table 1: Characteristics and skills of a leader

\begin{tabular}{|c|c|}
\hline \multicolumn{2}{|c|}{ Characteristics and skills of a leader } \\
\hline Features & Skills \\
\hline $\begin{array}{ll}- & \text { openness, } \\
- & \text { communication, } \\
- & \text { determination, } \\
- & \text { reliable, } \\
- & \text { energetic, } \\
- & \text { persistent, } \\
- & \text { resistant to } \\
& \text { stress, } \\
- & \text { adapted to } \\
& \text { situations, } \\
- & \text { responsible, } \\
- & \text { efficient, } \\
- & \text { fair and more. }\end{array}$ & $\begin{aligned}- & \text { creative, } \\
- & \text { professional, } \\
- & \text { possesses } \\
- & \text { organizational } \\
& \text { skills, } \\
- & \text { communication, } \\
- & \text { expertise, } \\
- & \text { power to } \\
& \text { persuade, } \\
- & \text { intelligence and } \\
& \text { others. }\end{aligned}$ \\
\hline
\end{tabular}

Stogdill (1974) presented the research in the field of leadership and confirmed that there are certain features that distinguish the leader from the rest. Characteristics and skills that any leader has, and that highlight from the others, Stogdill presents in Table 1.
What separates the leader from the other people in the organization? A successful leader has many positive features. The staff have great respect for the leader, because of the characteristics that he owns, which are mutual for all successful leaders, such as:

- Visionary - The leader looks into the future and has a clear vision for the organization. $\mathrm{He}$ has a vision and goals and creates a team that will accomplish goals.

- Honesty - Honesty is always on the top of the list of leadership characteristics. A leader knows that employees want to follow someone with integrity and honest character. Employees want to know that they are led by someone with strong character and that they can trust the leader when he is making difficult choices. Honesty is appreciated by all. Leaders must have vision, passion, respect, charisma, communication skills, but without real sincerity and without strict adherence to its principles, he can quickly lose the trust of the staff.

- Inspiring - The leader uses inspiration to motivate others to see the vision of the organization. He must have a vision and to know how to communicate the same with the others in the organization. A loyalty towards an organization requires motivation by the one who leads it. The leader is the person who encourages and inspires the employees, and he is the one who should enable the employees to feel comfortable and good, either as employees and as people.

- Efficient - Employees like a leader who is efficient and effective, and above all a leader who shows knowledge. He must know how to solve problematic situations. A great leader must see things from several different angles before taking any decision.

- Fair - From the leader it is expected to be fair and to make any decision in a way that will be respected by others. Fair leader respects both sides of the work and develops a policy that will be perceived by the rest of the organization.

- Communicative - The leader is a person who based on communication skills builds confidence among employees. He knows how to share his knowledge with others, to build 
confidence and create a working atmosphere in the organization.

- Courage - From the leaders is expected to show courage and take a risk, to take care of customers, and above all for the employees and for the organization. Bravely to look to the future and not be afraid to take every given opportunity for advancement of the organization and the employees. He must be innovative and offer new solutions to exit from the newly created crisis.

Table 2: Differences between leaders and managers

\begin{tabular}{|c|c|}
\hline \multicolumn{2}{|c|}{ Differences between leaders and managers } \\
\hline Leader & Manager \\
\hline $\begin{array}{l}\text { - } \text { Builds relationship and trust } \\
\text { - } \quad \text { Strategic orientation } \\
\text { - } \text { Provide direction } \\
\text { - Provides guidance and counsel } \\
\text { - } \quad \text { Creates an environment for } \\
\text { change } \\
-\quad \text { Questions rules and regulations } \\
-\quad \text { Motivates and inspires } \\
-\quad \text { Works follow their example } \\
-\quad \text { Trains and teaches }\end{array}$ & $\begin{array}{ll}- & \text { Maintains control and order } \\
- & \text { Follows rules and regulations } \\
- & \text { Technical orientation } \\
- & \text { Follow orders } \\
- & \text { Planning } \\
- & \text { Organizing and staffing } \\
- & \text { Controlling and solves problems }\end{array}$ \\
\hline
\end{tabular}

A manager does not necessarily equal a leader. The biggest differentiator between managers and leaders is how they motivate their employees to take an action. Managers are more focused on short-term goals or objectives, they motivate through a command, leaders focus on long-term goals, and they inspire, motivate and are focused on the greater mission. Leaders can combine the change with growth, take risks and demonstrate problem-solving abilities. The leader must have a significant energy level, physical stamina, and stress tolerance. Leadership requires the ability to solve problems and draw out those to creatively resolve issues along the way. The leader needs to be flexible with ideas and open to a variety of solutions and viewpoints.

A leader must be able to transform his vision into a more inclusive position by gaining the trust and commitment of those needed to fulfill his objective. The success of a leader depends on his ability to achieve a goal through the actions of those involved. It takes the commitment of others in the organization to implement a leader's vision and goals. The society and the organizations must have effective leadership in order to successfully achieve their objectives. Trust is indirectly proportional to risk. To increase trust, leaders must decrease risk. The employees in one organization must have the trust in their leader.

According to Raymond Cattell, a pioneer in the field of personality assessment, who has developed the Leadership Potential Equation in 1954, the effective leaders have those basic attributes or characteristics:

- Emotional stability - The leaders must be able to tolerate frustration and stress.

- Dominance - Leaders are often competitive and decisive and usually enjoy overcoming obstacles.

- Enthusiasm - Leaders are usually seen as active, expressive and energetic.

- Conscientiousness - Leaders are often dominated by a sense of duty and tend to be very exacting in character. They usually have very high standard of excellence and an inward desire to be the best.

- Social boldness - Leaders tend to be spontaneous risk-takers.

- Tough-mindedness - Good leaders are practical, logical and to-the-point.

- Self-assurance - Self-confidence and resiliency are common attributes among leaders. They tend to be free of guilt and have little or no need for approval. 
- High energy - long hours and travel are usually a prerequisite for leadership positions, especially as the company grows.

- Intuitiveness - rapid changes in the world today combined with information overload result in an inability to "know" everything. The leaders must trust their "gut" when they are making decisions.

- Maturity - to be a good leader, personal power and recognition must be secondary to the development of the employees.

- Team orientation - Business leaders today put a strong emphasis on teamwork.

- Empathy - Being able to "put yourself in the other person's shoes" is a key attribute of leaders today.

- Charisma - Leaders who have charisma are able to arouse strong emotions in their employees by defining a vision which unites.

- Compulsiveness - Leaders were found to be controlled and very precise in their social interactions. (AU, n.d.)

\section{RESISTANCE TO ORGANIZATIONAL CHANGES}

Every successful and experienced leader knows that the change process is always accompanied by resistance to the same. The fear of the new situation causes resistance to new organizational changes among the employees. The fear of the new, the unexpected, the fear of losing positions or general fear of change is a major obstacle to the implementation of changes. The leaders of the changes need to take into consideration the resistance and create mechanisms and appropriate strategies to lower or completely eliminate it, allowing an uninterrupted flow of the changes.

There are a great number of factors that create resistance: Economic factors, job security, image, prestige and reputation, threat for the comfort, misunderstanding of the initiator of the change, distrust in the organizational change, fear of the unknown, threat to the power of organizational and individual level, the habits etc.

To avoid these situations, the leader of organizational changes should have his own strategies to deal with the resistance towards the organizational change.

\section{THE ROLE OF THE LEADER IN THE ELIMINATION OF THE RESISTANCE AND IN THE SUCCESSFUL INTRODUCTION OF CHANGES}

The role of every successful leader is to undertake appropriate steps to reduce the resistance to the organizational change, and by this reduction or removal allow the change process to run continuously and to achieve the desired objectives. A leader takes care that the changes are accepted by the employees in the organization. Every leader knows that any change must not be taken if it is not connected with the increase of the efficiency and effectiveness of the operating of the organization, and all of that, should not have a huge influence on the operation of the company.

Before any change in the organization, the leader needs to create a vision and strategy for the future guidelines to be taken by him, to make good preparations, to avoid surprises, and to create an atmosphere for the changes. The leader should undertake the following activities in order to reduce the organizational changes:

- to create conditions for implementation of the changes,

- support and understanding of the changes,

- working teams for implementation of the changes,

- communicate the vision for change etc.

One of the approaches towards solving of the resistance to the change is that there is a need to get an answer the following three questions:

1. Why are changes needed?

2. What to change? and

3. How to initiate the change? (Postolov, p. 55)

As a way of reducing the resistance to the change, the leader includes employees in creating a vision and strategy for the desired goals, and thus the trust between the leader and the employees is on a high level.

In order to implement the changes and accomplish the purpose of the same, the leader has to inform the employees about the process of changes and what impact the changes will have on them and the environment where they work or what they will gain and lose with the changes. An effective 
leader knows that only with good communication the changes can be initiated, that is one-way communication (top-down) has to be avoided or in the worst case to hide information from the employees. Only with trust and good communication which should be continued and supported by relevant information in all directions, the goals of the organization can be achieved.

The successful leader creates a team that will move the process of change towards the goal. Creates new allies inside and outside the organization, and he is thinking globally and not locally.

\section{CONCLUSION}

Successful leaders in the organizations are surrounded by successful people and successful working teams, know how to lead and motivate, and above all have the ability to encourage changes in the right time when it is needed. The success of the organizational change depends on many features that the leader who is leading the process of change should have. To manage a change, the leader needs to ensure that the organization is ready or rather that employees are willing to join and embrace the change. A strategy for change is needed to be prepared, how, when and why changes are needed. With well-prepared vision, with clear targets and tasks to prepare the organization for the new process of transformation from a state that no longer functions in the new desired state the process of the changes will be successful.

The leader needs to know how and when to inform employees about the process that has to be accepted by them, and the employees themselves should help and involve themselves in the process to achieve the targeted goals. Without the support of the employees, the process of change will be doomed to the precipice at the beginning. In favor to the achievement of successful change the communication between the leader and employees should be on a high level in all directions. The leader must know how to communicate because only with good communication the leader can motivate employees in reaching the goals. Employees respect the honest leader, and this is why the communication should be sincere and with clear messages. Informing the employees of each phase of the change allows to avoiding any surprise and creation of any obstacle in the way of the introduction of the organizational change.

The development of management today allows managers to apply various skills and methods in managing the organizations. Possession of knowledge by managers - leaders increases the possibility of successful implementation of change and the removal of the resistance towards the same. According to Perry Smith, the leader should be a good teacher. The teaching of the others to work and achieve higher performance in the operation is only one of the characteristics of a successful leader. He is not afraid to share his knowledge and information with others, guides them and teaches them how to work and thus motivate them in their work.

The successful leader knows that in order to succeed he has to motivate the others, to be creative and open to all. Motivation is a key factor in the change process. Only with well-motivated people, a leader indulges into the organizational change. He uses a variety of methods and techniques of motivation in any situation and thus keeps employees' morale high in the difficult and decisive moments not only for the organization but also for them.

The organizational changes are needed for any organization that is looking in the future, they are permanent and decisive for the success of the organization. Their introduction in the organization is not a process without end. Each process has its beginning, the process of change and the end (achieving the objectives). But if the changes are introduced in the organization, this does not mean that the leadership and the employees can rest and turn away their attention out of changes. It often occurs that after the introduction of changes, employees slowly return to the old way of working. The leader cannot allow a situation like this, so he must control and institutionalize the change and does not allow the return to the old situation. Following the introduction of the organizational changes, the leader knows that the same must also be celebrated. Celebrating and rewarding the employees is necessary because of the possibility in the future to easier introduce new changes.

In times of globalization changes are quick and virtually unpredictable so that an organization cannot be static and firmly stick to the past, but 
with the help of the changes to provide itself clearer and more secure future. The role of the leader is to recognize the signs or rather threats to the organization in the right time and to convert the same into possibilities or changes for the organization, and in this way create the possibility the organization to come out of the current situation and go boldly towards the goals. Successful and good prepared leader leads the organization with a vision and clearly defined objectives, with courageous steps towards those objectives. As a true leader, he is responsible for the errors that occur during the process of change and does not allow the same to negatively affect the organization. He knows that a major mistake at any stage of the process of change is catastrophic for the same and therefore the leader controls, gives and receives the information from the employees, which allows changes to flow without any problems and the obstacles or threats to be promptly disposed of.

Changes are always followed by the resistance to the same from the employees who have a fear of the new working situations. In these key moments, the focus is put on the characteristics of the leader to firmly stand behind the changes and to lead the organization together with its employees to the accomplishment of the goals set.

\section{WORKS CITED}

AU. (n.d.). Leadership Traits - Small Business Administration. Retrieved 04 25, 2016, from The Air University: http://www.au.af.mil/au/awc/awcgate/sba/traits.htm

Drucker, P. (1999). Management's New Paradigms, Management Challenges for the 21st Century. New York.

Hausladen, R. J. (2008, Sep.). Leaders are not born; They Are Grown. Retrieved from New Horizons: http://www.newhorizonspcs.com/leaders_are_not_born_they_are_grown.html

Kiteva Rogleva, N., Gegovska-Zajkova, S., \& Fustik, V. (2014, 07 15). Leadership skills of the young professionals in industry and other institutions - a case study for master students. (Z. Čekerevac, Ed.) MEST Journal, 2(2), 86-94. doi:10.12709/mest.02.02.02.09

Kouzes, J. M., \& Posner, B. Z. (2012). The Leadership Challenge (Fourth ed.). San Francisco, USA: Jossey-Bass.

Postolov, C. (n.d.). Managing the organizational change - A factor for improving the competitiveness of the Macedonian economy.

Ristic, S., \& Cekerevac, Z. (2012). Development of leadership competence and self-improvement of the leaders. Komunikacie (Communications)(2), 76-81. Retrieved from http://www.cekerevac.eu/biblioteka/ij_19.pdf

Stogdill, R. M. (1974). Handbook of Leadership: A Survey of Theory and Research. Free Press.

Received for publication:

Revision received:

Accepted for publication:
20.03.2016

24.05.2016

10.06.2016

\section{How to cite this article?}

Style - APA Sixth Edition:

Zuka, J. (2016, July 15). The role of the leader in the success of the changes in an organization. (Z.

Čekerevac, Ed.) MEST Journal, 4(2), 176-184. doi:10.12709/mest.04.04.02.20

Style - Chicago Sixteenth Edition: 
Zuka, Jeton. 2016. "The role of the leader in the success of the changes in an organization." Edited by Zoran Čekerevac. MEST Journal (MESTE) 4 (2): 176-184. doi:10.12709/mest.04.04.02.20.

Style - GOST Name Sort:

Zuka Jeton The role of the leader in the success of the changes in an organization [Journal] // MEST Journal / ed. Čekerevac Zoran. - Belgrade : MESTE, July 15, 2016. - 2 : Vol. 4. - pp. 176-184.

Style - Harvard Anglia:

Zuka, J., 2016. The role of the leader in the success of the changes in an organization. MEST Journal, 15 July, 4(2), pp. 176-184.

Style - ISO 690 Numerical Reference:

The role of the leader in the success of the changes in an organization. Zuka, Jeton. [ed.] Zoran Čekerevac. 2, Belgrade : MESTE, July 15, 2016, MEST Journal, Vol. 4, pp. 176-184. 